\title{
RESPON SPEKTRAL BEBERAPA JENIS ANAKAN \\ TANAMAN PERKOTAAN TERHADAP \\ PENCEMARAN UDARA
}

CATTLEYA RIFDAH SEPTIANDANI

DEPARTEMEN KONSERVASI SUMBERDAYA HUTAN DAN EKOWISATA

FAKULTAS KEHUTANAN INSTITUT PERTANIAN BOGOR

BOGOR

2021 


\section{PERNYATAAN MENGENAI SKRIPSI DAN SUMBER INFORMASI SERTA PELIMPAHAN HAK CIPTA}

Dengan ini saya menyatakan bahwa skripsi dengan judul "Respon Spektral Beberapa Jenis Anakan Tanaman Perkotaan terhadap Pencemaran Udara" adalah karya saya dengan arahan dari dosen pembimbing dan belum diajukan dalam bentuk apa pun kepada perguruan tinggi mana pun. Sumber informasi yang berasal atau dikutip dari karya yang diterbitkan maupun tidak diterbitkan dari penulis lain telah disebutkan dalam teks dan dicantumkan dalam Daftar Pustaka di bagian akhir skripsi ini.

Dengan ini saya melimpahkan hak cipta dari karya tulis saya kepada Institut Pertanian Bogor.

Bogor, Juni 2021

Cattleya Rifdah Septiandani

E34160073 
ABSTRAK

CATTLEYA RIFDAH SEPTIANDANI. Respon Spektral Beberapa Jenis Anakan Tanaman Perkotaan terhadap Pencemaran Udara. Dibimbing oleh RACHMAD HERMAWAN dan ARIF KURNIA WIJAYANTO.

Pemilihan jenis tanaman merupakan faktor penting yang menentukan keberhasilan pembangunan hutan untuk menanggulangi pencemaran udara. Penggunaan teknologi spektral diharapkan dapat menjadi terobosan dalam pemilihan jenis tanaman. Penelitian ini bertujuan untuk menguji perbedaan respon spektral beberapa jenis anakan tanaman pada area tercemar dengan kurang tercemar dan menentukan tingkat ketahanan beberapa jenis anakan tanaman berdasarkan respon spektral. Penelitian ini dilaksanakan pada bulan Juli - Agustus 2020 di Tol Jagorawi Bogor Km 43 yang dibagi menjadi area tercemar dan kurang tercemar. Alat utama yang digunakan untuk pengambilan nilai radiasi spektral adalah HandHeld 2 Spectroradiometer. Metode clustering digunakan untuk menentukan klasifikasi tinggi, sedang, dan rendah, sedangkan besarnya perubahan nilai spektral pada dua area untuk menentukan ketahanan tanaman. Hasil menunjukkan bahwa terdapat perbedaan respon spektral tanaman antara area tercemar dan kurang tercemar. Urutan tingkat ketahanan tanaman terhadap pencemaran udara yaitu: mahoni, ketapang, akasia, tanjung, dan nyamplung.

Kata kunci : clustering, kurang tercemar, respon spektral, tercemar.

\section{ABSTRACT}

CATTLEYA RIFDAH SEPTIANDANI. Spectral Response of Several Species of Urban Plant to Air Pollution. Supervised by RACHMAD HERMAWAN and ARIF KURNIA WIJAYANTO.

The choice of plant species is an important factor determining the success of urban forest development to overcome air pollution in urban areas. The use of spectral technology is expected to be a breakthrough in the selection of plant species. This study aims to examine differences in the spectral response of several species of plant seedlings in a polluted area with a less polluted area and determine the resistance level of several plant seedlings based on the spectral response. This research was conducted in July - August 2020 at Jagorawi toll road Bogor km 43 which is divided into polluted area and less polluted area. The main tool used for obtaining spectral radiation values is the HandHeld 2 Spectroradiometer. The clustering method was used to determine the high, medium, and low classification, while the value of the changes in the spectral vaues in two areas was to determine plant resistance. The result showed that there were differences in plant spectral responses between polluted and less polluted areas. The order of the level of plant resistance to air pollution is: mahogany, ketapang, acacia, tanjung, and nyamplung.

Keyword : clustering, less polluted, polluted, spectral response. 


\section{RESPON SPEKTRAL BEBERAPA JENIS ANAKAN \\ TANAMAN PERKOTAAN TERHADAP PENCEMARAN UDARA}

\section{CATTLEYA RIFDAH SEPTIANDANI}

\section{Skripsi}

sebagai salah satu syarat untuk memperoleh gelar

Sarjana pada

Program Studi Konservasi Sumberdaya Hutan dan

Ekowisata 


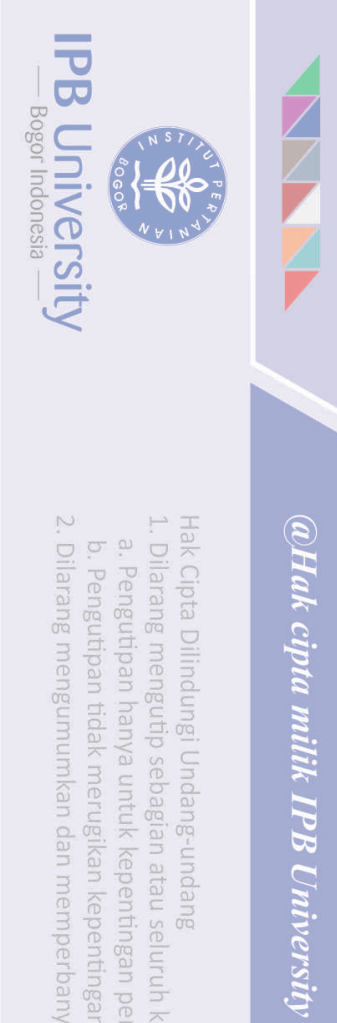

TimPenguji pada Ujian Skripsi:

0 Dr. Ir. Prijanto Pamoengkas, MSc.F.Trop 
Judul Skripsi : Respon Spektral Beberapa Jenis Anakan Tanaman Perkotaan terhadap Pencemaran Udara

Nama : Cattleya Rifdah Septiandani

NIM : E34160073

Disetujui oleh

Pembimbing 1:

Dr. Ir. Rachmad Hermawan, MSc. F.Trop

3

Pembimbing 2:

Arif Kurnia Wijayanto, S.TP, MSc
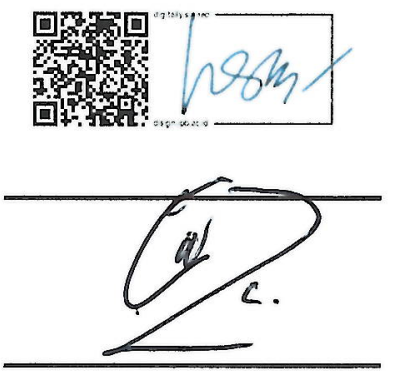

Ketua Program Studi:

Dr Ir Nyoto Santoso MS

NIP 196203151986031002

Diketahui oleh

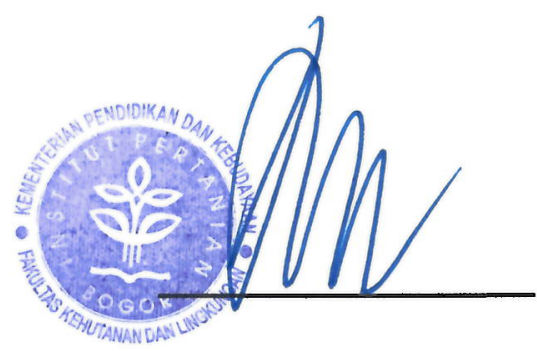




\section{PRAKATA}

Puji dan syukur penulis panjatkan kepada Allah subhanaahu wa ta'ala atas segala karunia-Nya sehingga karya ilmiah ini berhasil diselesaikan. Tema yang dipilih dalam penelitian yang dilaksanakan sejak bulan Juli 2020 sampai bulan Agustus 2021 ini ialah, dengan judul "Respon Spektral Beberapa Jenis Anakan Tanaman Perkotaan terhadap Pencemaran Udara".

Terima kasih penulis ucapkan kepada para pembimbing, Bapak Dr. Ir. Rachmad Hermawan, MSc. F.Trop dan Bapak Arif Kurnia Wijayanto, S.TP, M.Sc yang telah membimbing dan banyak memberi saran. Ucapan terima kasih juga disampaikan kepada pembimbing akademik, moderator seminar, dan penguji luar komisi pembimbing. Di samping itu, penghargaan penulis sampaikan kepada kepada Bapak Hadi, Mbak Salas, dan Mas Ade dari LAPAN yang telah memeberikan arahan dan bantuan peminjaman alat. Terima kasih juga saya ucapkan kepada Ibu Devi, Bapak Ari, dan dan tim lapangan daerah Baranangsiang dari Dinas Perumahan dan Pemukiman Kota Bogor. Terima kasih juga kepada Ibu Vivi dari Badan Meteorologi, Klimatologi, dan Geofisika stasiun Klimatologi Bogor yang sudah membantu penulis memberikan data curah hujan. Terima kasih kepada teman satu bimbingan saya Rahma Yunita dan Irvan Agustian yang telah membantu dalam proses penyususnan proposal hingga skripsi.

Ungkapan terima kasih juga disampaikan kepada Ayah, Ibu, serta seluruh keluarga besar Achmad Soeparno yang telah memberikan dukungan, doa, dan kasih sayangnya. Ungkapan terima kasih juga penulis sampaikan kepada seluruh Dosen dan Staff DKSHE, sahabat-sahabat saya (Alhalimata, Amaliya, Karin, Nabilla, Faisal, Jasmine, Imelda, Diba, Angelina, Ilham, Febrina, Angga, Audelia, Sarasnada, Karina, Syahnidar, Azzahra, Ayu Nawang, Aulan, Siti Kamalia, Afifah dan Warga Rumah Bawean), keluarga besar Axis kuhlii (DKSHE 53) dan Elephasis (FAHUTAN 53) atas segala doa dan dukungannya sehingga penulis dapat menyelesaikan tulisan ini.

Semoga karya ilmiah ini bermanfaat bagi pihak yang membutuhkan dan bagi kemajuan ilmu pengetahuan..

Bogor, Juni 2021

Cattleya Rifdah Septiandani 


\section{DAFTAR ISI}

DAFTAR TABEL vii

DAFTAR GAMBAR vii

DAFTAR LAMPIRAN vii

$\begin{array}{lll}\text { I PENDAHULUAN } & 10\end{array}$

$\begin{array}{ll}1.1 \quad \text { Latar Belakang } & 10\end{array}$

1.2 Tujuan 2

1.3 Hipotesis Penelitian 2

1.4 Manfaat Penelitian 2

II METODE 3

$2.1 \quad$ Waktu dan Tempat 3

2.2 Alat dan Bahan 4

2.3 Jenis Data 5

2.4 Metode Pengumpulan Data 6

$\begin{array}{lll}2.5 & \text { Pengolahan Data } & 7\end{array}$

2.6 Analisis Data 9

$\begin{array}{lr}\text { III HASIL DAN PEMBAHASAN } & 10\end{array}$

3.1 Kondisi Umum Lokasi Penelitian 10

3.2 Perbandingan Nilai Respon Spektral di Area Tercemar dan Kurang Tercemar 11

3.3 Penentuan Jenis Anakan Tanaman yang Tahan Terhadap Pencemaran Udara $\quad 15$

$\begin{array}{lr}\text { IV SIMPULAN DAN SARAN } & 18\end{array}$

$\begin{array}{lll}4.1 & \text { Simpulan } & 18\end{array}$

$\begin{array}{lll}4.2 & \text { Saran } & 18\end{array}$

$\begin{array}{ll}\text { DAFTAR PUSTAKA } & 19\end{array}$

$\begin{array}{ll}\text { LAMPIRAN } & 21\end{array}$

$\begin{array}{ll}\text { RIWAYAT HIDUP } & 25\end{array}$ 


\section{DAFTAR TABEL}

Komponen, sumber, dan metode pengumpulan data

Panjang gelombang kanal biru, hijau, merah, dan infra-merah dekat

(Nera Infra-red/NIR) pada citra satelit Landsat 8

Hasil perhitungan clustering pada gelombang biru, hijau, merah, dan NIR

Tabel hasil selisih klasifikasi clustering

\section{DAFTAR GAMBAR}

Peta lokasi penelitian 3

Plot lokasi penelitian $\quad 4$

Alat HandHeld 2 Spectroradiometer 4

Bibit pohon akasia, nyamplung, ketapang, tanjung, dan mahoni 5

Flow chart pengolahan data perbandingan nilai respon spektral $\quad 8$

Nilai respon spektral lima jenis pohon pada area tercemar $\quad 12$

Nilai respon spektral lima jenis pohon pada area kurang tercemar $\quad 12$

Perbandingan rata-rata nilai respon spektral dari kedua area 13

Grafik perbandingan nilai respon spektral pada gelombang biru, hijau, merah, dan NIR

\section{DAFTAR LAMPIRAN}

Lampiran tabel pengelompokkan nilai spektral pada gelombang biru

$\begin{array}{ll}\text { Lampiran tabel pengelompokkan nilai spektral pada gelombang merah } & 21\end{array}$

Lampiran tabel pengelompokkan nilai spektral pada gelombang hijau 22

Lampiran tabel pengelompokkan nilai spektral pada gelombang NIR 22

Lampiran data harian curah hujan bulan Juli 2020 - Agustus $2020 \quad 22$

Lampiran Hasil perhitungan clustering gelombang biru dengan SPSS 23

Lampiran Hasil perhitungan clustering gelombang merah dengan SPSS 23

Lampiran Hasil perhitungan clustering gelombang hijau dengan SPSS 24

Lampiran Hasil perhitungan clustering gelombang NIR dengan SPSS 


\section{PENDAHULUAN}

\subsection{Latar Belakang}

Kawasan perkotaan adalah kawasan yang mempunyai kegiatan utama bukan pertanian, dengan fungsi kawasan sebagai tempat pemukiman perkotaan, pemusatan dan distribusi pelayanan jasa pemerintahan, pelayanan sosial dan kegiatan ekonomi yang disebutkan dalam Undang-undang No 26 Tahun 2007 tentang Penataan Ruang. Aktivitas yang berada dalam area perkotaan turut menyumbang emisi gas $\mathrm{CO}_{2}$. Pesatnya perkembangan kota meningkatkan permasalahan pencemaran udara yang bersumber dari transportasi yang merupakan penyumbang emisi gas $\mathrm{CO}_{2}$. Emisi gas $\mathrm{CO}_{2}$ yang dihasilkan dari kegiatan antropogenik konsentrasinya relatif lebih tinggi sehingga dapat mengganggu sistem keseimbangan di udara dan menyebabkan kerusakan lingkungan.

Kemacetan lalu lintas merupakan salah satu akibat dari kegiatan antropogenik yang terjadi di kota-kota besar dan sangat mengganggu aktivitas penduduk, karena dapat menimbulkan dampak negatif bagi kesehatan manusia dan lingkungan. Kemacetan lalu lintas di area perkotaan disebabkan oleh meningkatnya perkembangan di area pusat kota yang menyebabkan tingginya tingkat penggunaan trasnportasi yang dapat menimbulkan pencemaran udara. Kemacetan juga merupakan penyebab emisi gas $\mathrm{CO}_{2}$ semakin bertambah dan menyebabkan peningkatan suhu daerah perkotaan. Selain dari gas $\mathrm{CO}_{2}$, pencemaran udara juga berasal dari gas-gas rumah kaca. Efek rumah kaca adalah proses pemanasan permukaan bumi yang diakibatkan oleh meningkatnya suhu udara di atmosfer. Permukaan bumi menyerap sebagian panas dan memantulkan kembali sisanya (Purbaya 2016). Gas $\mathrm{CO}_{2}$ dapat meningkatkan suhu udara dengan menyerap gelombang near infrared (Chou 1990), sehingga menjadi penting untuk diperhatikan karena kontribusinya paling besar terhadap peningkatan suhu udara (Henning 1990).

Pengembangan Ruang Terbuka Hijau (RTH) merupakan salah satu cara untuk menanggulangi pencemaran udara. Peran dan fungsi Ruang Terbuka Hijau ditetapkan dalam Instruksi Mendagri No.4 Tahun 1988 yang menyatakan Ruang Terbuka Hijau yang populasinya didominasi oleh penghijauan baik secara alamiah atau budidaya tanaman, dalam pemanfataan dan fungsinya adalah sebagai areal berlangsungnya fungsi ekologis dan penyangga kehidupan wilayah perkotaan. Masing-masing pohon memiliki fungsi yang berbeda, pohon dengan fungsi utamanya menyerap $\mathrm{CO}_{2}$ yang dibutuhkan untuk menurunkan suhu dan meminimalisir pencemaran udara. Menurut Grey dan Deneke (1978), tanaman dapat mengurangi polutan udara dengan proses oksigenisasi.

Pemilihan jenis tanaman merupakan kunci utama keberhasilan membangun hutan kota. Kondisi lingkungan kota yang kurang kondusif menuntut jenis tanaman yang tahan terhadap berbagai faktor cekaman lingkungan, salah satunya adalah pencemaran udara. Selama ini penelitian yang bertujuan untuk mengkaji ketahanan tanaman yaitu dengan melihat produktivitas tanaman. Penelitian ini memerlukan waktu cukup lama dan biaya yang relatif mahal.

Oleh karena itu dengan berkembangnya teknologi pengukuran radiasi spektral diharapkan dapat menjadi terobosan dalam pemilihan jenis tanaman 
dengan cepat. Usaha yang dilakukan untuk mengembangkan dalam teknologi pencahayaan, dapat menjadikan usaha positif untuk memperoleh cahaya dengan spektrum yang lebih baik (Zakrzewska 2014). Radiasi spektral merupakan salah satu cara dengan mengandalkan jumlah dari energi pancaran termal dari per satuan luas benda pemancarnya. Dalam diskursus pencahayaan buatan, ditemukan tidak semua cahaya digunakan tanaman, namun lebih spesifik lagi ternyata cahaya spektrum merah dan biru yang efisien digunakan untuk fotosintesis dari pada seluruh spektrum cahaya tampak (Carney et al 2015, Syafriyudin 2015, dan Aldaghi et al 2016). Radiasi spektral merupakan jumlah energi pancaran termal per sึatuan luas permukaan benda pemancar. Secara tidak langsung pendugaan ini menghubungkan nilai radiasi spektral dengan kemampuan fotosintesis suatu jenis tumbuhan (Purbaya 2016).

\section{Tujuan}

Tujuan penelitian ini adalah sebagai berikut:

a. Menguji perbedaan respon spektral beberapa jenis anakan tanaman yang berada di area tercemar polutan udara dengan area kurang tercemar polutan udara.

b. Menentukan tingkat ketahanan beberapa jenis anakan tanaman berdasarkan respon spektral.

\subsection{Hipotesis Penelitian}

Respon spektral jenis anakan tanaman yang terpapar oleh pencemaran udara berbeda dengan jenis anakan tanaman yang tidak terpapar oleh pencemaran udara.

\subsection{Manfaat Penelitian}

Manfaat dari penelitian ini yaitu dapat digunakan sebagai dasar pengembangan metode pemilihan jenis tanaman dengan cepat. 


\section{METODE}

\subsection{Waktu dan Tempat}

Penelitian dilaksanakan pada Juli 2020 - Agustus 2020. Lokasi penelitian dilaksanakan di Jalan Tol Jagorawi km 43 yang meliputi dua area yaitu: a) area tercemar yang memiliki kepadatan kendaraan yang tinggi; b) area kurang tercemar yang memiliki kepadatan kendaraan relatif rendah. Alasan penelitian ini dipilih di area Tol Jagorawi berdasarkan kepadatan kendaraan relatif tinggi dibandingkan lokasi lain di wilayah Kota Bogor kemudahan dalam teknis pelaksanaan penelitian, dan keamanan penempatan anakan. Tol Jagorawi memiliki panjang jalan $59 \mathrm{~km}$ dan dioperasikan mulai tahun 1978 oleh PT. Jasa Marga yang merupakan jalan tol pertama yang dioperasikan. Jalan Tol Jagorawi menghubungkan Jakarta, Cibubur, Citereup, Bogor, dan Ciawi (Suprayitno 2012). Lokasi penelitian di Jalan Tol Jagorawi digambarkan pada Gambar 1.
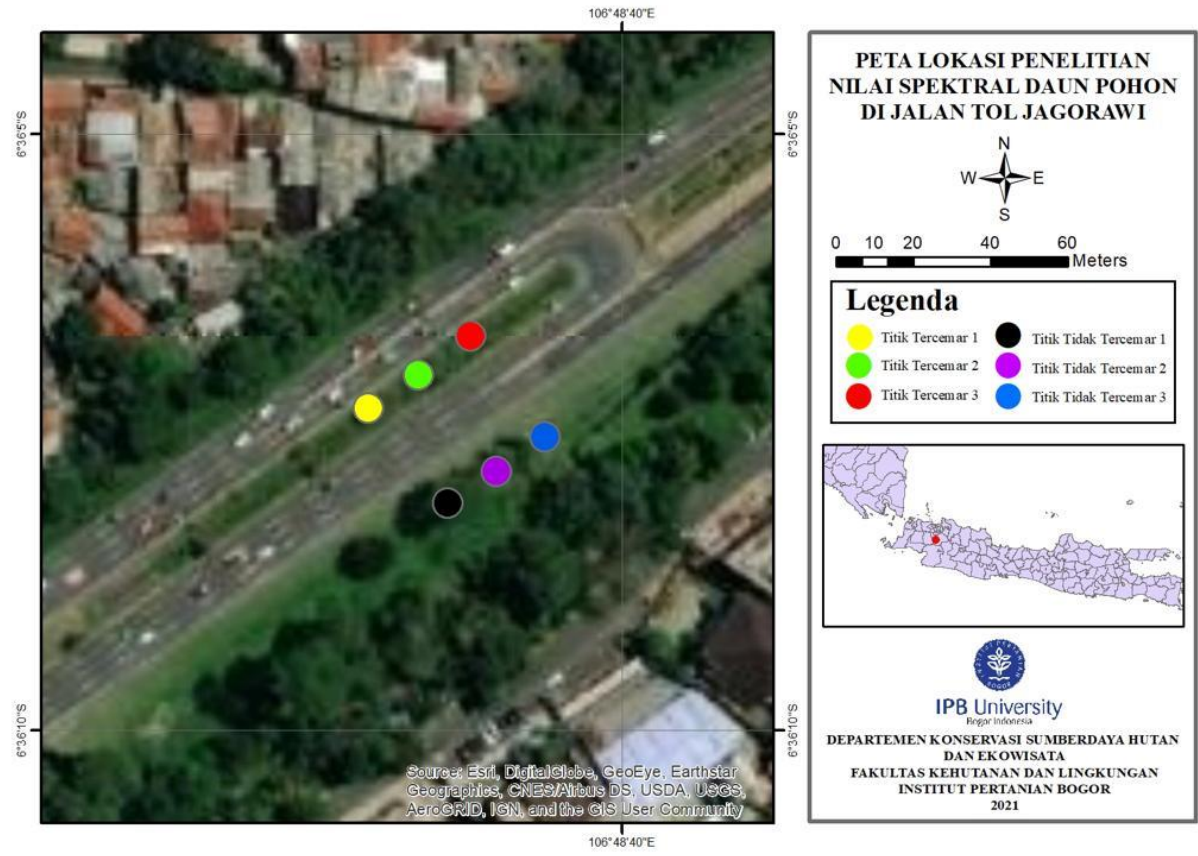

Gambar 1 Peta lokasi penelitian

Penelitian dilakukan pada dua lokasi yang berbeda yaitu di median jalan tol dan bahu jalan tol sebelah selatan dengan jarak $12 \mathrm{~m}$ dari tepi jalan. Anakan tanaman yang diletakkan di median jalan diasumsikan terpapar polutan udara yang lebih berat karena dipengaruhi oleh emisi kendaraan dari dua jalur jalan, sedangkan anakan tanaman yang terletak di bahu jalan diasumsikan terpapar polutan udara yang relatif ringan karena hanya dipengaruhi emisi kendaraan dari satu jalur jalan. Terdapat enam plot pada lokasi penelitian dengan masing-masing tiga plot pada area tercemar dan kurang tercemar yang berisi sepuluh anakan tanaman pada setiap plot. Pembagian pada kedua lokasi ini digambarkan pada Gambar 2. 


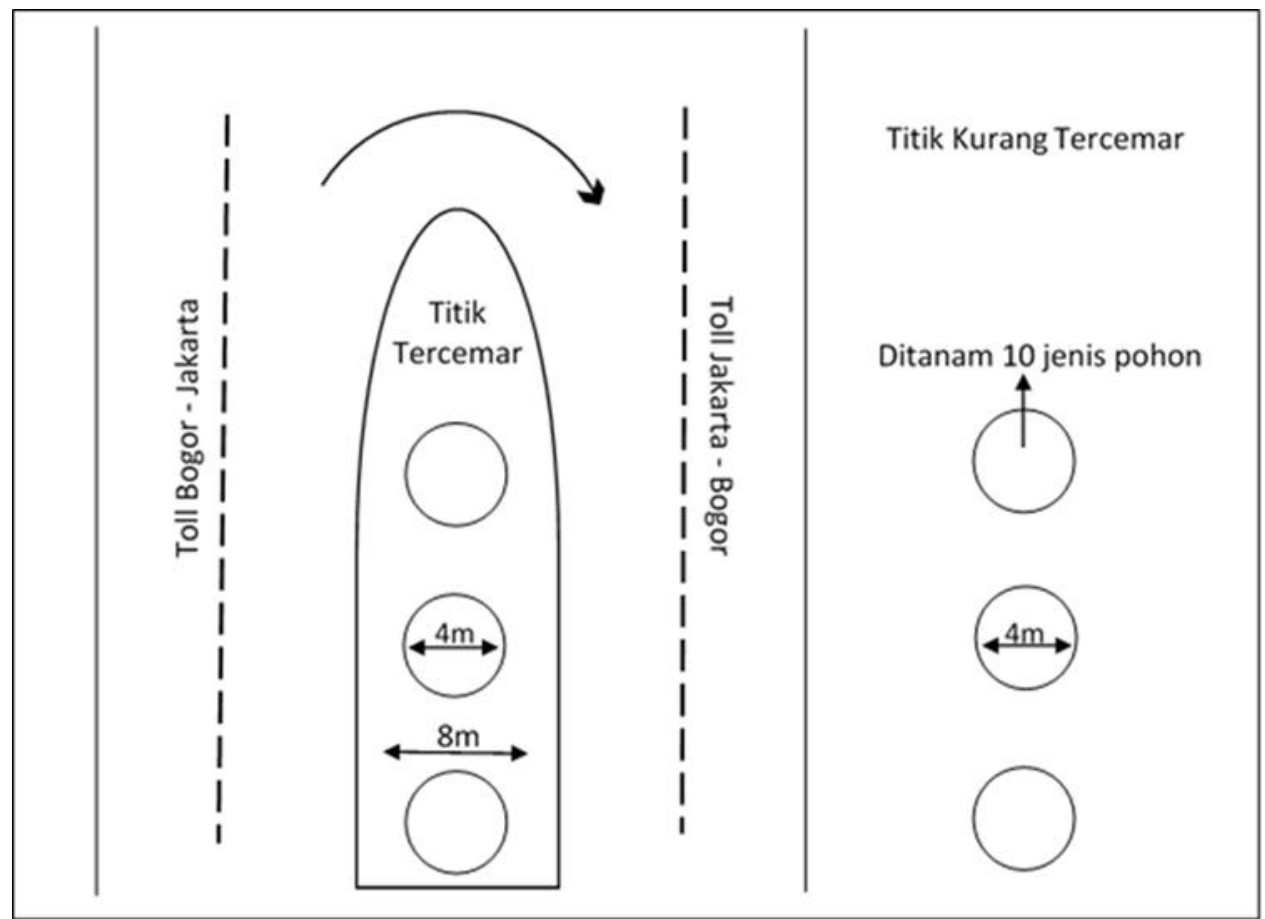

Gambar 2 Plot lokasi penelitian

\subsection{Alat dan Bahan}

Alat yang digunakan dalam penelitian ini adalah HandHeld 2 Spectroradiometer (Gambar 3). HandHeld 2 Spectroradiometer digunakan untuk mengukur nilai radiasi spektral dari daun, dan alat ini termasuk dalam alat pengukur spektral genggam yang dirancang untuk mengukur radiasi spektral dari cahaya tampak (visible) hingga near-infrared dan menganalisis pada rentang spektral 325$1075 \mathrm{~nm}$. Alat dan bahan lainnya yang digunakan yakni: kain hitam, alat tulis, laptop, aplikasi multi counter dan tally sheet. Adapun software yang digunakan untuk proses mengolah data yakni, Microsoft Excel, software HH 2 Sync, dan software View Spec Pro.
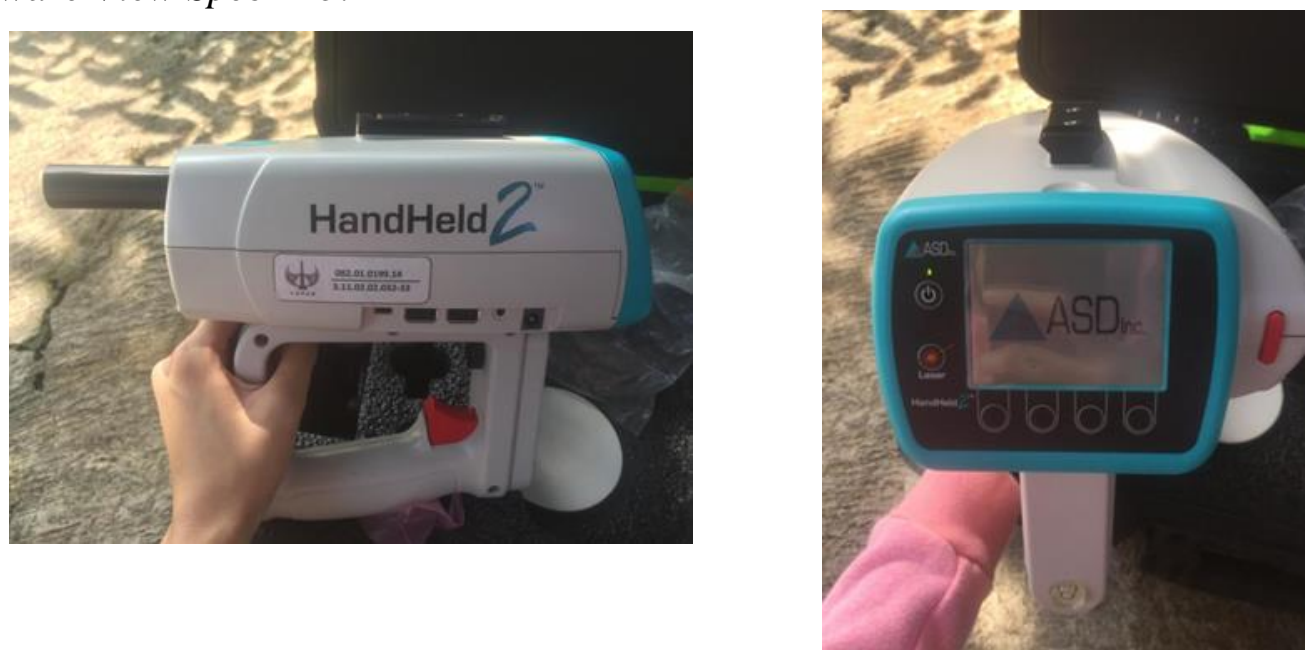

Gambar 3 Alat HandHeld 2 Spectroradiometer 
Objek penelitian yang digunakan merupakan sampel daun dari lima jenis anakan tanaman. Jenis tanaman yang dipilih merupakan jenis tanaman yang banyak digunakan untuk Ruang Terbuka Hijau Kota, yaitu ketapang (Terminalia catappa), mahoni (Swietenia mahagoni), tanjung (Mimusops elengi), akasia (Acacia mangium), dan nyamplung (Calophyllum inophyllum). Lima jenis anakan pohon yang digunakan berumur empat bulan dengan tinggi $60 \mathrm{~cm}$ (Gambar 4). Pemilihan jenis anakan pohon mengacu berdasarkan Dahlan (1992). Penelitian ini menggunakan 60 anakan dari lima jenis yang berbeda yang diletakkan pada area yang dekat dengan sumber pencemar dan jauh dari sumber pencemar dengan melakukan pengulangan pengukuran sebanyak tiga kali pada jenis anakan yang sama. Setiap plot dari masing-masing lokasi ditanam 10 anakan dari lima jenis yang berbeda.

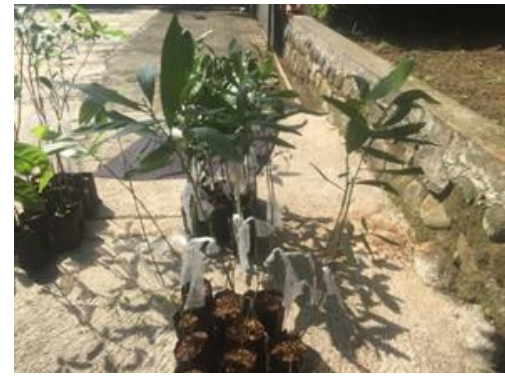

(a)

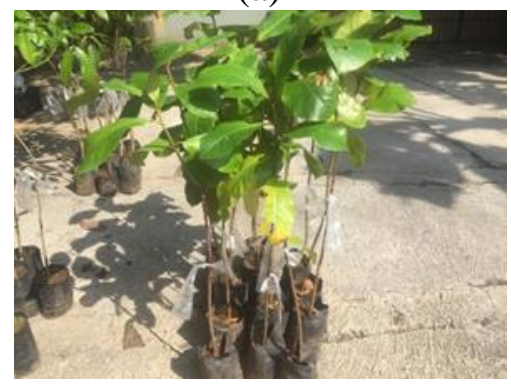

(c)

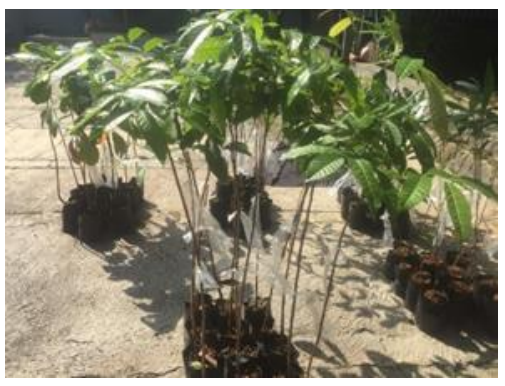

(b)

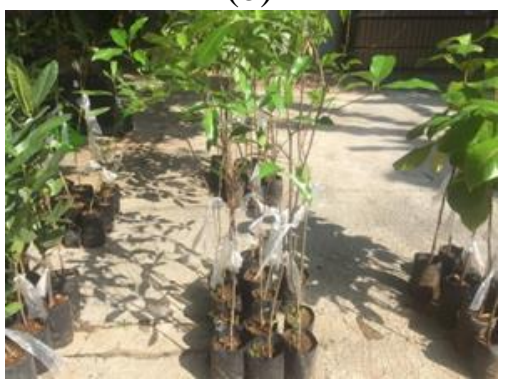

(d)

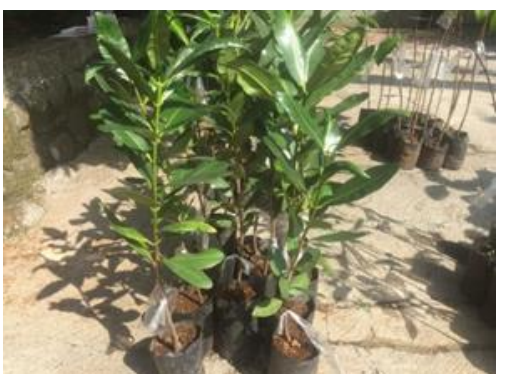

(e)

Gambar 4 Anakan pohon (a) akasia, (b) mahoni, (c) ketapang, (d) tanjung, dan (e) nyamplung

\subsection{Jenis Data}

Data yang dikumpulkan dalam penelitian ini terdiri atas data primer dan data sekunder. Data primer merupakan data utama yang digunakan adalah data nilai radiasi spektral daun dari masing-masing jenis anakan. Data primer lainnya yang digunakan adalah data volume kendaraan sebagai data pendukung. Sementara itu, 
data sekunder merupakan data yang diperoleh melalui studi pustaka. Data sekunder dapat mendukung data primer.

Data curah hujan yang didapatkan dari Stasium Klimatologi Bogor. Data dan informasi kondisi umum lokasi tersebut diperoleh dari, publikasi jurnal ilmiah, laporan, serta karya ilmiah lainnya yang terkait dengan penelitian ini. Data dan jenis Gata yang dibutuhkan dalam penelitian beserta sumber data disajikan pada Tabel 1.

\begin{tabular}{|c|c|c|c|}
\hline \multicolumn{4}{|c|}{ Tabel 1 Komponen, sumber, dan metode pengumpulan data } \\
\hline Jenis data & $\begin{array}{l}\text { Kategori } \\
\text { data }\end{array}$ & Sumber data & Metode pengumpulan data \\
\hline $\begin{array}{l}\text { Nilai radiasi } \\
\text { spektral daun } \\
\text { pohon }\end{array}$ & Primer & $\begin{array}{l}\text { Hasil } \\
\text { pengukuran }\end{array}$ & $\begin{array}{l}\text { Pengukuran nilai spektral } \\
\text { dengan menggunakan alat } \\
\text { HandHeld } 2 \\
\text { Spectroradiometer }\end{array}$ \\
\hline Curah hujan & Sekunder & $\begin{array}{l}\text { Stasiun } \\
\text { Klimatologi } \\
\text { Bogor, BMKG }\end{array}$ & $\begin{array}{l}\text { Penelusuran data curah hujan } \\
\text { harian }\end{array}$ \\
\hline $\begin{array}{l}\text { Data volume } \\
\text { kendaraan }\end{array}$ & Primer & $\begin{array}{l}\text { Hasil } \\
\text { pengukuran }\end{array}$ & $\begin{array}{l}\text { Pengukuran } \\
\text { kendaraan di } \\
\text { penelitan }\end{array}$ \\
\hline
\end{tabular}

\subsection{Metode Pengumpulan Data}

Pengambilan data nilai spektral radiasi dari masing-masing jenis pohon yang berbeda, dilakukan selama dua bulan pada bulan Juli 2020 - Agustus 2020. Pengambilan data dilakukan setiap dua minggu sekali setelah penempatan anakan tanaman di lokasi penelitian. Pengambilan data lainnya yaitu data volume kendaraan diambil saat rentang waktu pengambilan data nilai spektral radiasi pada saat hari libur dan hari kerja dengan pembagian waktu pada pagi, siang, dan sore hari.

\subsubsection{Pengambilan Data Nilai Respon Spektral}

Penelitian dilakukan dengan pengumpulan data menggunakan metode observasi lapang, dan studi pustaka. Anakan pohon yang dijadikan sampel yaitu berjumlah lima jenis anakan pohon yang diletakkan di dua lokasi utama yaitu area yang dekat dengan sumber pencemar dan area yang jauh dari sumber pencemar dan terlindungi vegetasi. Tahap awal penelitian semua anakan diaklimatisasi di lokasi yang sama yaitu di rumah peneliti yang berlokasi di Jalan Gugah Sari, Dramaga, Bogor, guna menyamakan kondisi pada setiap anakan pohon sebelum di tanam di lokasi utama penelitian.

Sebelum pengambilan data di lokasi penelitian, anakan tanaman ditanam di area yang sudah ditentukan, untuk menghindari resiko hilangnya anakan. Setelah dilakukan penanaman, anakan tanaman dibiarkan beradaptasi terlebih dahulu dengan kondisi lingkungan sekitarnya.

Setiap dua minggu sekali dilakukan pengukuran spektral radiasi pada pagi hari hingga siang hari, karena waktu tersebut merupakan waktu yang efektif untuk tumbuhan berfotosintesis. Sebelum mengambil data nilai spektral, dilakukan dulu 
persiapan alat dengan mengatur pengaturan integration time agar saat pengambilan data tidak terjadi saturation atau terjadi banyaknya cahaya yang terserap. Setelah itu dilakukan pengkalibrasian dahulu pada alat dengan mengarahkan lensa ke arah white reference untuk kalibrasi. Kalibrasi pada alat dilakukan setiap kali pergantian sampel. White reference harus beralaskan kain hitam. Kain hitam berfungsi untuk meminimalisir adanya cahaya kontras yang masuk saat proses kalibrasi alat. Lalu langkah selanjutnya adalah mengarahkan alat ke objek dengan bantuan fitur laser agar lensa mengarah tepat pada daun dengan sudut $90^{\circ}$ dengan jarak alat ke daun kurang lebih $50 \mathrm{~cm}$, agar objek tidak terhalang bayangan alat ataupun bayangan manusia. Pengambilan data dilakukan sebanyak tiga kali pengulangan pada masingmasing jenisnya. Alat secara otomatis menangkap nilai spektral radiasi daun. Nilai radiasi spektral akan tersimpan otomatis dalam format text document (.txt). Pengambilan data pertama dilakukan dua minggu setelah anakan diletakkan dilokasi, lalu pengambilan data selanjutnya dilakukan setiap satu minggu sekali.

\subsubsection{Pengambilan Data Kepadatan Kendaraan}

Pengambilan data kepadatan kendaraan dilakukan untuk menentukan lokasi penelitian yang mempunyai potensi tercemar paling berat, yaitu di Jalan Tol Jagorawi, Kebun Raya Bogor, Taman Ekspresi Sempur, Pintu dua Kampus IPB Dramaga, dan Taman Lodaya. Kriteria untuk lokasi penelitian yaitu, volume kendaraan pada tempat tersebut harus cukup padat baik pada waktu akhir pekan maupun waktu hari kerja.

Pengambilan data dilakukan selama 2 minggu pada waktu hari kerja dan akhir pekan. Minggu pertama pengambilan pada hari Senin dan Sabtu, sedangkan pada minggu kedua diambil pada hari Kamis dan Minggu. Alat yang digunakan yaitu aplikasi Multi Counter dari Smartphone dan tally sheet. Pengambilan data kepadatan kendaraan dibagi menjadi tiga waku yaitu pada waktu pagi, siang, dan sore hari selama 30 menit pada setiap waktunya. Pengambilan data kepadatan kendaraan dibedakan menjadi kategori mobil pribadi, motor, angkutan umum, dan kendaraan besar seperti bus dan truk. Pengambilan data dilakukan pada dua jalur yang berbeda, Jalur Bogor-Jakarta dan Jalur Jakarta-Bogor.

\subsubsection{Data Curah Hujan}

Data curah hujan merupakan data sekunder yang didapatkan dari Stasiun Klimatologi Bogor. Data curah hujan ini merupakan data harian pada bulan Juli hingga bulan Agustus Tahun 2020. Data curah hujan digunakan sebagai data penunjang untuk membahas kondisi umum lokasi penelitian.

\subsection{Pengolahan Data}

Data spektral yang didapat merupakan hasil pengukuran reflektansi dari alat HandHeld 2 Spectroradiometer pada rentang panjang gelombang $325 \mathrm{~nm}-1075$ $\mathrm{nm}$. Pengolahan data menggunakan software Ms. Excel. Nilai radiasi spektral dari alat masih berupa format .txt, lalu diubah mejadi format Ms Excel . Nilai panjang gelombang yang digunakan yaitu gelombang merah dan biru, karena sebagai gelombang cahaya matahari yang efektif untuk melakukan fotosintesis (Rabinowitch 1951; Handoko dan Fajariyanti 2013; Campbell et al. 2010 ). Selain panjang gelombang merah dan biru, nilai pada panjang gelombang hijau dan NIR 
juga digunakan. Tabel 2 menunjukkan panjang gelombang pada setiap kanalnya. Perhitungan analisis data membagi spektrum cahaya pada panjang gelombang biru, hijau, merah, dan NIR berdasarkan citra Landsat 8.

Tabel 2 Panjang gelombang kanal biru, hijau, merah, dan infra-merah dekat (Near Infra-red/NIR) pada citra satelit Landsat 8

\begin{tabular}{lll} 
Kanal & Panjang Gelombang $(\mu \mathrm{m})$ \\
\hline Biru & $0.450-0.515$ \\
Hijau & $0.525-0.600$ \\
Merah & $0.630-0.680$ \\
NIR & $0.845-0.885$
\end{tabular}

Sumber: https://landsat.gsfc.nasa.gov/landsat-8/landsat-8-bands/ tahun publikasi 2013

(diakses pada tanggal 17 September 2020)

Nilai radiasi spektral dari alat masih berupa format .txt. Sebelum melakukan pengolahan data, data yang dipindahkan dari alat tidak bisa langsung diolah dengan Microsoft Excel, melainkan harus dikonversi terlebih dahulu dengan software $\mathrm{HH}$ 2 Sync dan software View Spec Pro. Dari hasil satu kali pengambilan nilai radiasi spektral anakan pohon dari satu sampel didapatkan hasil tiga kali pengulangan pengukuran. Flow chart pengolahan data seperti pada Gambar 5.

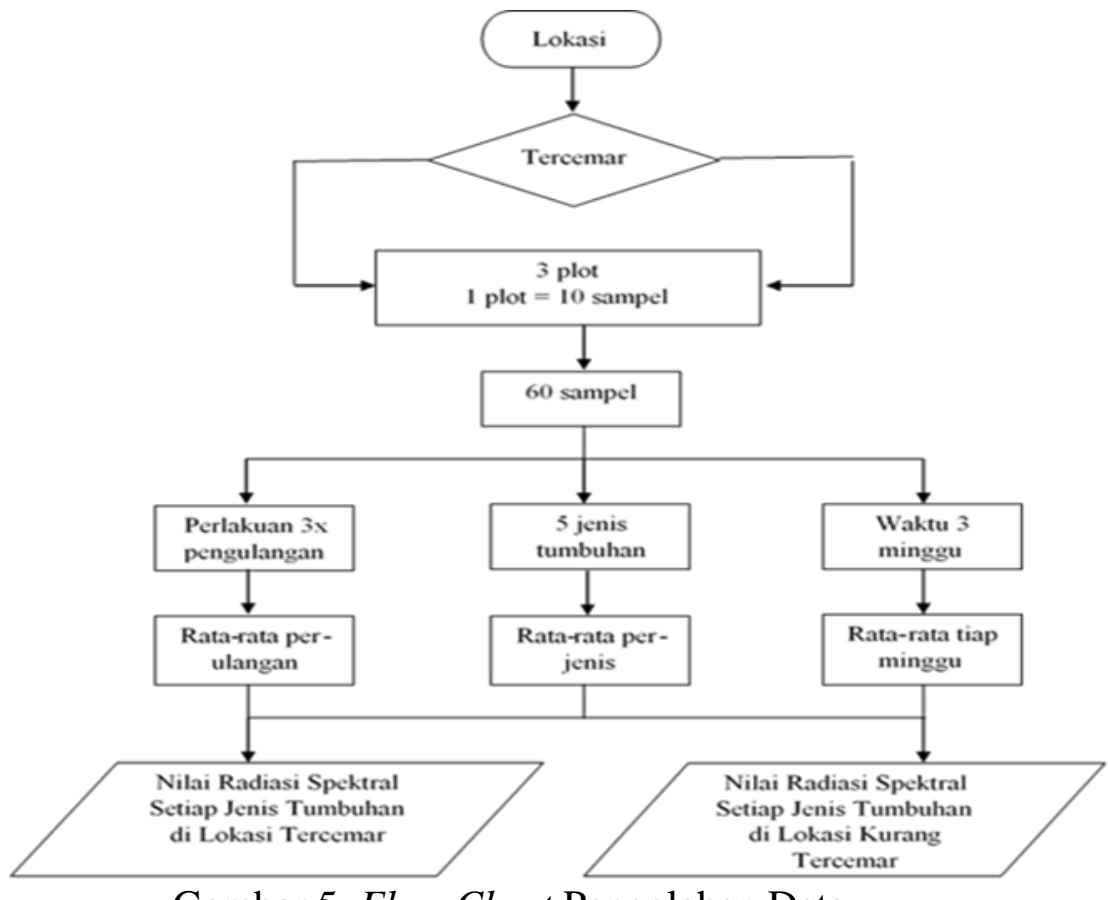

Gambar 5 Flow Chart Pengolahan Data

Metode clustering ini digunakan untuk mengelompokkan respon spektral jenis anakan berdasarkan panjang gelombangnya (biru, hijau, merah, NIR) menjadi kategori tinggi, sedang, dan rendah. Metode clustering yang digunakan untuk melakukan analisis adalah metode clustering k-means. K-means merupakan salah satu metode pengelompokan data non-hierarki yang mempartisi data yang ada ke 
dalam bentuk dua atau lebih kelompok. Metode ini mempartisi data ke dalam kelompok sehingga data berkarakteristik sama dimasukkan ke dalam satu kelompok yang sama dan data yang berkarakteristik berbeda dikelompokkan ke dalam kelompok yang lain (Prasetyo 2012).

Nilai spektral daun diurutkan dari nilai terendah hingga nilai tertinggi. Nilai spektral radiasi berbanding terbalik dengan hasil fotosintesis, maka dari itu daun yang memiliki nilai spektral radiasi terendah memiliki daya serap $\mathrm{CO}_{2}$ paling tinggi. (Purbaya 2016).

\subsection{Analisis Data}

Analisis data dilakukan untuk menentukan tingkat ketahanan tanaman berdasarkan perbedaan respon spektral tanaman pada gelombang biru, hijau, merah, dan NIR antara area tercemar dan kurang tercemar. Berdasarkan hasil clustering, maka ada tiga klasifikasi respon spektral yaitu rendah, sedang, dan tinggi. Untuk memudahkan dalam proses penentuan urutan tingkat ketahanan, maka perlu kuantifikasi klasifikasi rendah, sedang, dan tinggi. Klasifikasi rendah diberi nilai 1, klasifikasi sedang diberi nilai 2, dan klasifikasi tinggi diberi nilai 3.

Setiap jenis tanaman ditentukan perbedaan nilai klasifikasi yang diperoleh berdasarkan dari penjumlahan perbedaan nilai klasifikasi antara area kurang tercemar dengan area tercemar pada gelombang biru, hijau, merah, dan NIR. Semakin besar perbedaan nilai klasifikasi, maka jenis tanaman diduga semakin kurang tahan terhadap pencemaran udara, demikian juga sebaliknya. 


\section{HASIL DAN PEMBAHASAN}

\subsection{Kondisi Umum Lokasi Penelitian}

Jalan Tol Jagorawi dengan panjang $59 \mathrm{~km}$ menghubungkan Jakarta, Cibubur, Citeureup, Bogor dan Ciawi yang tersambung dengan ruas jalan tol Dalam Kota, Lingkar Luar Jakarta dan Bogor Ring Road. Saat ini terdapat 17 gerbang tol yaitu pjada Ramp TMII (Timur dan Barat), Ramp Dukuh 2, Cibubur (1, 2, 3 dan Utama), Cimanggis (Golf, dan Utama), Gunung Putri, Karangan, Citeureup, Sentul, Sentul Selatan (1 dan 2), Bogor dan Ciawi (Satriaputri dan Cahyadi 2015). Jalan Tol Jagorawi memiliki topografi yang datar (kelerengan 0-2\%), berombak (3-8\%), dan tergelombang (9-15\%). Ketinggian tempat wilayah Tol Jagorawi bervariasi, sekitar 20-300 m dpl. Berdasarkan klasifikasi tipe curah hujan Schmidth-Ferguson, Jalan Tol Jagorawi termasuk dalam wilayah yang memiliki iklim tipe A, yaitu mempunyai curah hujan rata-rata yang lebih besar dari $2000 \mathrm{~mm} /$ tahun. Kondisi tanahnya didominasi oleh lapisan liat yang cukup dalam (Hidayat 2008).

Bulan Juli hingga Agustus termasuk musim kemarau, tetapi pada saat bulan Juli hingga Agustus 2020 terdapat beberapa hari yang mengalami hujan. Stasiun curah hujan yang berdekatan untuk memantau curah hujan di lokasi penelitian sekitar Baranangsiang terdapat di Pos Kebun Raya. Rata-rata curah hujan kota Bogor pada bulan Juli yaitu 9,6 mm sedangkan pada bulan Agustus 38,9 mm yang tersaji pada Lampiran 5. Hujan dapat mempengaruhi pemberian perlakuan pada objek terhadap pencemaran pada daerah sekitarnya. Air hujan dan angin dapat menyapu polusi yang sudah terpapar pada permukaan daun yang sudah terpapar oleh polusi dari kendaraan bermotor, mobil, dan kendaraan besar seperti bus atau truk. Tumbuhan melalui daunnya dapat menangkap partikel timbal yang diemisikan kandaraan bermotor (Djuangsih dalam Siringoringo 2000), Menurut Koeppe dan Miller dalam Siringiringo, kemampuan tanaman dalam menjerap timbal sangat dipengaruhi keadaan permukaan daun tanaman tersebut.

Minggu pertama data diambil pada waktu hari kerja dan akhir pekan. Hasil pengambilan data volume kendaraan minggu pertama pada waktu hari kerja di Jalur Bogor-Jakarta lebih padat dengan jumlah total kendaraan 6.946/hari, sedangkan pada Jalur Jakarta-Bogor berjumlah 6.173/hari. Waktu akhir pekan volume kendaraan Jalur Jakarta-Bogor lebih padat dengan jumlah 6.974/hari daripada Jalur Bogor-Jakarta dengan jumlah 6.295/hari. Hasil sampel pengambilan data volume kendaraan pada minggu kedua, pada waktu hari kerja Jalur Bogor-Jakarta lebih padat dengan jumlah 7.954/hari, sedangkan Jalur Jakarta-Bogor dengan jumlah 6.288/hari. Waktu akhir pekan Jalur Jakarta-Bogor lebih padat dengan jumlah 8.126/hari daripada Jalur Bogor-Jakarta dengan jumalah 7.954/hari. Kepadatan kendaraan menjadi penyumbang pencemaran udara oleh polusi kendaraan. Salah satu pencegahannya dengan cara membuat jalur hijau atau dengan melakukan penanaman jenis pohon yang efektif untuk menyerap polusi. 


\subsection{Perbandingan Nilai Respon Spektral di Area Tercemar dan Kurang Tercemar}

\subsubsection{Respon Spektral}

Pengolahan data dilakukan pada panjang gelombang biru, hijau, merah, dan NIR dengan rentang 450-885 nm untuk melihat pola nilai spektral radisi pada masing-masing jenis tanaman. Nilai respon spektral berkisar antara nol dan satu dengan satuan W.cm $\mathrm{cm}^{-2} \cdot \mathrm{nm}^{-1} \cdot \mathrm{sr}^{-1}$. Purbaya (2016) menyebutkan, nilai respon spektral dapat menunjukkan berapa banyak daya per sentimeter persegi dan per nanometer per steradian dari cahaya matahari yang dipantulkan oleh daun, sehingga berdasarkan nilai tersebutlah dapat diketahui seberapa baik kemampuan suatu jenis daun pohon dalam memanfaatkan energi radiasi matahari untuk fotosintesis. Berdasarkan hal tersebut, kemampuan suatu jenis tanaman dalam memanfaatkan energi matahari untuk melakukan proses fotosintesis dapat diketahui keefektifannya. Proses fotosintesis tidak bergantung pada energi total cahaya, tetapi pada jumlah foton atau kuanta yang diserap. Foton adalah paket energi yang terpotong-potong, masing-masing mempunyai panjang gelombang tertentu (Salisbury 1992). Tumbuhan memanfaatkan energi matahari untuk melepaskan $\mathrm{O}_{2}$ dan mereduksi $\mathrm{CO}_{2}$ yang dilakukan untuk membentuk senyawa karbon yang lebih besar seperti glukosa.

Ada beberapa faktor abiotik yang dapat mempengaruhi proses fotosintesis yang bersih yang dapat mempengaruhi pertumbuhan dan produktivitas. Salah satu faktor terpentingnya yaitu cahaya matahari. Tidak hanya dipengaruhi oleh faktor abiotik, kemampuan fotosintesis juga dipengaruhi oleh umur dan posisi daun pada kanopi. Nilai respon spektral yang tinggi pada pohon di panjang gelombang biru dan merah maka akan semakin sedikit energi matahari yang dimanfaatkan pohon untuk fotosintesis. Pada proses fotosintesis, klorofil sangat berperan karena mampu menangkap cahaya matahari yang merupakan radiasi elektromagnetik pada spektrum kasat mata (Handoko dan Fajariyanti 2013).

Nilai respon spektral tersebut didapatkan dari hasil rataan tiga kali ulangan pengambilan data pada setiap sampel anakan pohon dari tempat yang dekat dengan sumber pencemar dan tempat yang jauh dari sumber pencemar. Grafik nilai respon spektral pada hasil penelitian ini sudah sesuai dengan pola grafik reflektan pada vegetasi. Grafik reflektan respon spektral pada vegetasi mempunyai bentuk pada panjang gelombang merah dan biru garis grafik akan menurun sedangkan pada gelombang hijau dan NIR garis grafik akan meningkat. Nilai respon spektral kedua lokasi dapat dilihat pada Gambar 6 dan 7. 


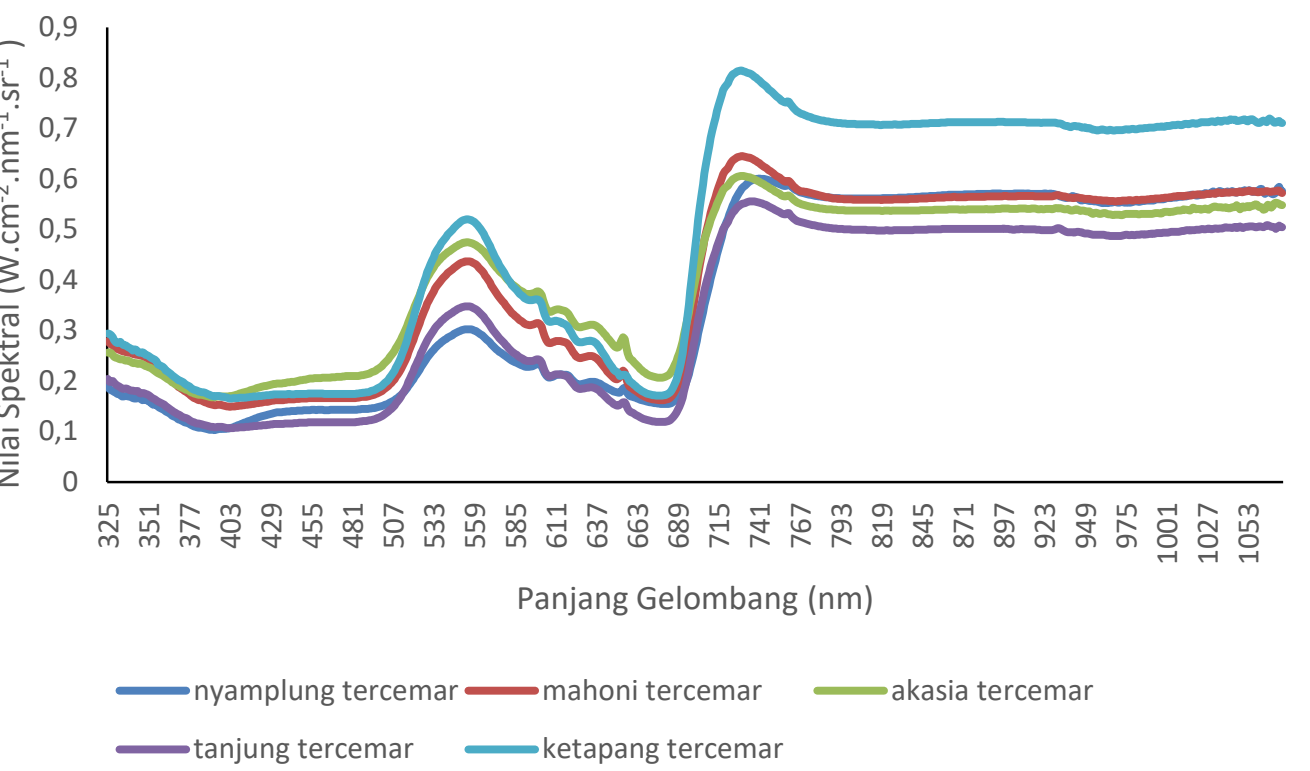

Gambar 6 Nilai respon spektral 5 jenis pohon pada area tercemar
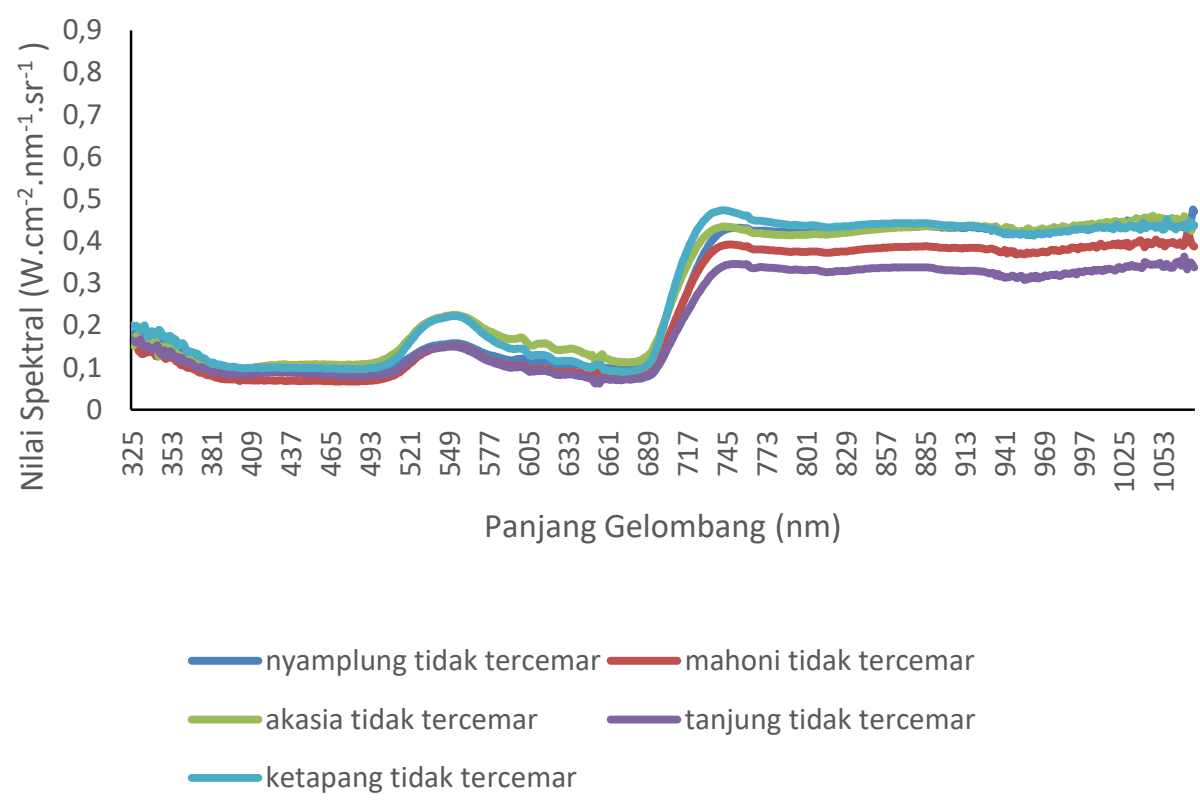

Gambar 7 Nilai respon spektral 5 jenis pohon pada area kurang tercemar

Hasil pengukuran nilai radiasi spektral pada lokasi yang dekat dengan sumber pencemar dan jauh dari sumber pencemar jenis dengan nilai respon spektral paling tinggi pada kedua lokasi tersebut adalah ketapang, sedangkan jenis terendah pada kedua lokasi tersebut adalah jenis tanjung dan mahoni. Pohon yang dapat menyerap polusi dengan baik memiliki tingkat kepadatan tajuk yang padat, dan memiliki jumlah daun yang banyak. Menurut Nasrullah (2001), untuk mengurangi jumlah polutan yang telah terlepas pada lingkungan dapat dikurangi dengan adanya vegetasi. Tanjung dapat hidup dengan baik ditempat-tempat yang terbuka dan kena sinar matahari langsung (Hendrasarie 2007). Kriteria pohon yang dapat menjerap debu dengan baik diantaranya harus memiliki permukaan daun yang kasar, 
berlekuk, berbulu dan bertrikoma, daun yang menjarum dan juga melebar, tajuk tanaman yang padat dan rapat, tekstur kulit batang dan ranting yang kasar serta berduri, dan kepadatan ranting yang rapat (Azzahro et al 2019).

Selain itu, kemampuan tumbuhan menyerap polusi juga dapat dilihat dari permukaan daun dan ketebalan daun. Daun yang tipis cenderung lebih efektif menyerap polusi. Bentuk daun yang lebar juga cenderung lebih efekif menyerap polusi karena memiliki luas permukaan daun yang besar. Polusi yang menempel pada daun juga dapat tersapu atau kadar penyerapan polusinya semakin rendah karena adanya pengaruh dari angin dan air hujan yang dapat menyapu polusi pada permukaan daun.

Rata-rata nilai respon spektral perbandingan lima jenis anakan pada kedua lokasi yang berbeda yang ditunjukkan pada Gambar 8. Pada daerah tercemar nilai respon spektralnya lebih tinggi dibandingan dengan hasil di daerah yang kurang tercemar. Hal ini serupa dengan penelitian Yong Zha et al (2012) yang dimana pada penelitiannya menyebutkan bahwa kabut asap meningkatkan nilai pantulan spektral dari semua jenis tutupan lahan. Namun pengaruh spektrum ini bervariasi dengan tutupan lahan yang berbeda. Selain itu hal ini juga sama dengan hasil klasifikasi Spectral Mixture Analysis (SMA) dalam buku elektronik laporan akhir LAPAN pada tahun 2014 yang menyebutkan di daerah tercemar dapat dilihat fraksi vegetasi tercemar memiliki persentase yang tinggi (warna piksel lebih terang) dibandingkan sekitarnya, sedangkan fraksi vegetasi kurang tercemar rendah dibandingkan sekitarnya.

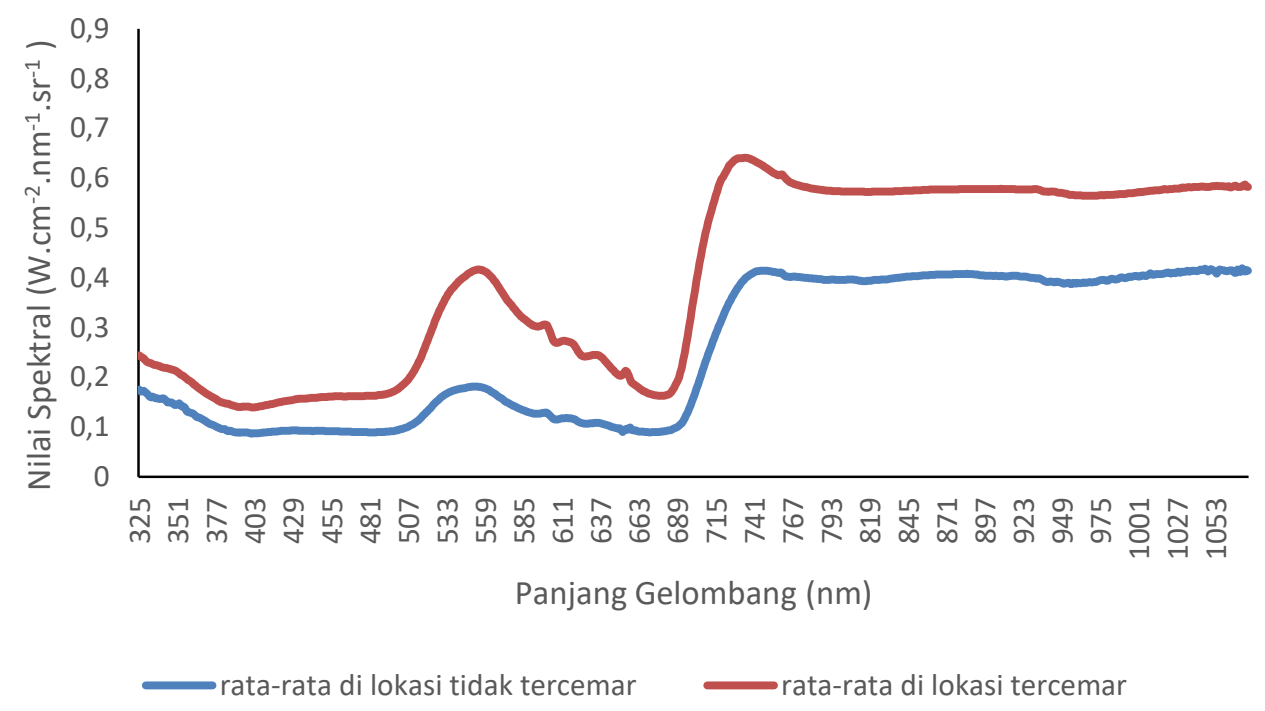

Gambar 8 Perbandingan rata-rata nilai respon spektral dari kedua lokasi

Nilai respon spektral pada tumbuhan merupakan pantulan dari radiasi matahari yang dimana hal tersebut sama dengan prinsip pemantulan cahaya yang dimana matahari yang datang dan menyentuh suatu permukaan dapat dipantulkan, diserap atau diteruskan. Sinar yang dipantulkan oleh sebuah objek merupakan reflektan atau reflektansi/pantulan, sedangkan absorbance/penyerapan adalah sinar yang diserap oleh sebuah objek yang terdapat pada panjang gelombang tertentu. Setiap objek yang berbeda memantulkan dan menyerap panjang gelombang yang berbeda (Lantana 2014). 


\subsubsection{Perbandingan Nilai Respon Spektral di Lokasi Tercemar dan Kurang Tercemar}

Hasil pengolahan data nilai respon spektral sudah dipisahkan berdasarkan masing-masing panjang gelombang yang digunakan yaitu panjang gelombang biru, bijau, merah, dan NIR. Panjang gelombang tersebut merupakan panjang gelombang yang baik untuk proses fotosintesis yang dimana berpengaruh pada hasil nilai respon spektral dari setiap jenis anakan. Hasil perbandingan ini didaptkan dari hasil fataan tiga kali pengulangan pada setiap jenisnya dan dirata-ratakan kembali data minggu kedua hingga minggu keempat. Dapat dilihat pada Gambar 9 yang merupakan histogram dari hasil perhitungan perbandingan dari tempat yang dekat dengan sumber pencemar dan tempat yang jauh dari sumber pencemar pada keempat gelombang.

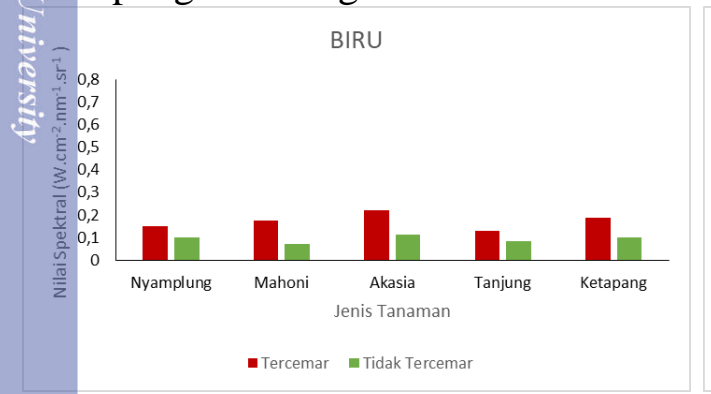

(a)

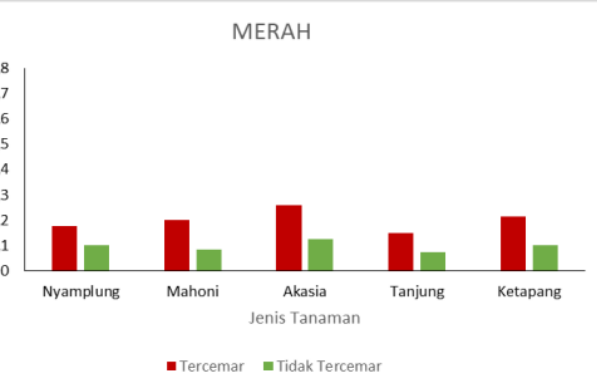

(c)

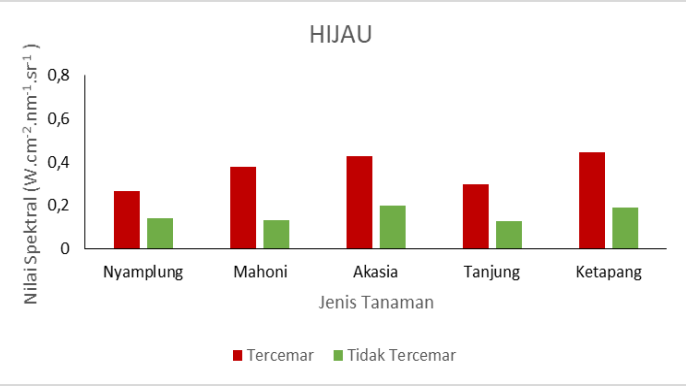

(b)

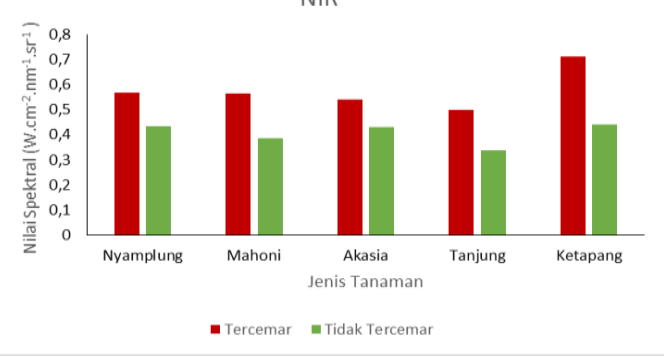

(d)

Gambar 9 Grafik perbandingan nilai respon spektral pada gelombang; (a) biru, (b) hijau, (c) merah, dan (d) NIR

Berdasarkan hasil pengamatan, didapatkan hasil nilai respon spektral anakan pada tempat yang dekat dengan sumber pencemar nilai respon spektralnya lebih tinggi dibandingkan dengan anakan yang berada di tempat yang jauh dari sumber pencemar. Pada gelombang biru dan merah, akasia mempunya nilai tertinggi pada lokasi tercemar dan kurang tercemar. Sedangkan jenis dengan hasil nilai terendah pada gelombang biru adalah tanjung pada daerah tercemar dan mahoni pada daerah kurang tercemar. Pada gelombang merah didapatkan hasil jenis tanjung pada kedua lokasi.

Nilai respon spektral gelombang hijau nilai tertingginya adalah jenis ketapang pada lokasi tercemar dan akasia pada lokasi kurang tercemar, sedangkan pada gelombang NIR jenis ketapang merupakan jenis dengan nilai tertinggi pada kedua lokasi. Pada fotosintesis dikenal istilah PAR (photosyntetically active radiation) adalah panjang gelombang yang efektif untuk fotosintesis berkisar antara 400-700 
nm. Istilah ini berhubungan dengan proses fotosintesis. Rentang panjang gelombang 400-700 nm disebut sebagai cahaya tampak/visible light (Triono 2004; Nyamsi et al. 2015; Qin et al. 2011; Pitman 2000).

Perhitungan nilai respon spektral tidak hanya pada gelombang merah dan biru saja yang merupakan panjang gelombang yang paling efektif untuk proses fotosintesis, melainkan menggunakan panjang gelombang hijau dan NIR juga. Tanaman yang sehat adalah tanaman yang respon spektral pada gelombang merah dan birunya rendah, dan nilai spektral pada gelombang hijau dan NIR nya tinggi.

\subsection{Penentuan Jenis Anakan Tanaman yang Tahan terhadap Pencemaran Udara}

\subsubsection{Pengelompokkan Nilai Respon Spektral}

Pengelompokkan nilai respon spektral terbagi menjadi tiga yaitu kelompok rendah, sedang dan tinggi. Pengelompokkan nilai respon spektral ini didapatkan dari hasil perhitungan statistik dengan menggunakan metode clustering atau metode penggerombolan. Metode clustering merupakan pengelompokkan data ke dalam sejumlah kelompok berdasarkan kesamaan karakteristik masing-masing data pada kelompok yang telah ada (Prasetyo 2012). Setelah dihitung dengan metode clustering, dilakukan perhitungan rata-rata nilai respon spektral pada gelombang biru, merah, hijau, dan NIR, gunanya untuk menghasilkan kelompok nilai respon spektral secara keseluruhan dan dijadikan acuan pengelompokkan kemampuan dari 5 jenis anakan dalam menyerap $\mathrm{CO}_{2}$. Rentang perhitungan yang digunakan dalam perhitungan hasil clustering menghasilkan beberapa hasil klasifikasi, yang dimana klasifikasi tersebut digambarkan dengan angka yaitu: angka 1 klasifikasi rendah, angka 2 klasifikasi sedang, dan angka 3 klasifikasi tinggi. Hasil perhitungan pengelompokkan nilai spektral pada gelombang biru, merah, hijau, dan NIR ditunjukan pada Tabel 3.

Tabel 3 Hasil perhitungan clustering pada gelombang biru, merah, hijau, dan NIR

\begin{tabular}{llllll}
\hline \multirow{2}{*}{ Lokasi } & \multirow{2}{*}{$\begin{array}{l}\text { Jenis } \\
\text { Tanaman }\end{array}$} & Biru & Merah & Hijau & NIR \\
\cline { 3 - 6 } & & Klasifikasi & Klasifikasi & Klasifikasi & Klasifikasi \\
\hline \multirow{4}{*}{ Tercemar } & Nyamplung & 2 & 2 & 2 & 2 \\
& Mahoni & 3 & 3 & 3 & 2 \\
& Tanjung & 2 & 2 & 2 & 2 \\
& Ketapang & 3 & 3 & 3 & 3 \\
& Akasia & 3 & 3 & 3 & 2 \\
\hline \multirow{4}{*}{ Kurang } & Nyamplung & 2 & 1 & 1 & 1 \\
Tercemar & Mahoni & 1 & 1 & 1 & 1 \\
& Tanjung & 1 & 1 & 1 & 1 \\
& Ketapang & 2 & 1 & 1 & 1 \\
\hline & Akasia & 2 & 1 & 1 & 1 \\
\hline
\end{tabular}

Keterangan: $1=$ rendah, $2=$ sedang, $3=$ tinggi 
Hasil pada gelombang biru dan merah secara berurut di kelompok tinggi yaitu jenis mahoni, ketapang dan akasia yang berada di lokasi tercemar. Pada gelombang biru didapatkan jenis tanaman mahoni dan tanjung pada kelompok rendah. Sedangkan pada gelombang merah didapatkan hasil jenis tanjung, mahoni, nyamplung, dan akasia. Selain kelompok rendah dan tinggi pada metode clustering ini juga terdapat kelompok sedang. Pada kelompok sedang, jenis tanaman pada golombang biru dan merah terbagi di lokasi tercemar dan kurang tercemar. Pada gelombang biru terdapat jenis nyamplung, ketapang, akasia pada lokasi kurang tercemar dan jenis tanjung dan nyamplung pada lokasi yang tercemar. Sedangkan pada gelombang merah terdapat jenis tanjung dan nyamplung pada lokasi tercemar. Hasil nilai respon spektral dari masing-masing panjang gelombang tersaji pada Eampiran 1-4.

\subsubsection{Ketahanan Jenis Anakan Tanaman terhadap Pencemaran Udara}

Laju fotosintesis daun tanaman dipengaruhi oleh beberapa faktor, yaitu kesehatan, ketersediaan air tanah dan kelembaban udara, konsentrasi gas $\mathrm{CO}_{2}$, intensitas cahaya matahari, fase pertumbuhan, letak daun, umur daun, perbedaan jenis tumbuhan, dan polutan udara (Dahlan 2008). Polutan udara merupakan indikator yang digunakan pada penelitian ini sebagai pemberian perlakuan pada objek untuk mengetahui jenis tanaman yang tahan terhadap pencemaran udara paling efektif menyerap polutan dari kelima jenis tanaman yang digunakan. Selain polutan udara, faktor umur juga berpengaruh pada penelitian ini, objek yang digunakan memiliki umur yang seragam. Dari kelima jenis semuanya berumur empat bulan.

Jenis anakan tanaman dengan nilai radiasi spektal rendah merupakan jenis anakan tanaman yang dapat tahan dalam keadaan lingkungan yang terpapar polusi. Selain hasil dari gelombang merah dan biru, adapun hasil dari gelombang hijau dan NIR. Pada gelombang hijau jenis yang terdapat pada kelompok tinggi yaitu jenis mahoni, akasia, dan ketapang yang terdapat pada daerah tercemar, sedangkan di gelombang NIR hanya ada jenis ketapang di lokasi tercemar. Kelompok sedang pada gelombang hijau terdapat jenis nyamplung dan tanjung pada lokasi tercemar, dan pada gelombang NIR terdapat jenis tanjung, akasia, mahoni, nyamplung pada lokasi tercemar. Urutan dan pengelompokan nilai respon spektral ini didapatkan dari hasil clustering, di rata-rata untuk mengelompokkan nilai respon spektral secara keseluruhan yang akan digunakan untuk mengetahui kemampuan jenis pohon yang tahan terhadap pencemaran udara. Perbedaan nilai klasifikasi respon spektral antara area yang tercemar dengan kurang tercemar untuk menentukan tingkat ketahanan tanaman seperti pada Tabel 4. 
Tabel 4 Tingkat ketahanan setiap jenis tanaman berdasarkan perbedaan nilai klasifikasi respon spektral

\begin{tabular}{llllll}
\hline \multirow{2}{*}{$\begin{array}{l}\text { Jenis } \\
\text { tanaman }\end{array}$} & \multicolumn{4}{l}{ Perbedaan Nilai Klasifikasi Respon Spektral } & \multirow{2}{*}{ Total } \\
\cline { 2 - 5 } Niru & Merah & Hijau & NIR & \\
Nyamplung & 0 & 1 & 1 & 1 & 3 \\
Mahoni & 2 & 2 & 2 & 1 & 7 \\
Tanjung & 1 & 1 & 1 & 1 & 4 \\
Ketapang & 1 & 2 & 2 & 2 & 7 \\
Akasia & 1 & 2 & 2 & 1 & 6 \\
\hline
\end{tabular}

Berdasarkan Tabel 4 diketahui bahwa jenis tanaman yang mempunyai perbedaan nilai klasifikasi yang semakin besar menunjukkan bahwa jenis tanaman tersebut kurang tahan terhadap pencemaran udara. Nyamplung mempunyai nilai perbedaan klasifikasi yang paling kecil sehingga dapat diartikan bahwa jenis ini diduga paling tahan terhadap pencemaran udara. Sebaliknya jenis yang ketahanannya kurang adalah jenis mahoni dan ketapang. 


\section{SIMPULAN DAN SARAN}

\subsection{Simpulan}

Terdapat perbedaan pada nilai respon spektral anakan tanaman perkotaan di area tercemar dan kurang tercemar pada setiap jenisnya. Secara umum nilai respon spektral anakan tanaman pada area tercemar lebih tinggi dibandingkan dengan area TKurang tercemar.

Berdasarkan perbedaan nilai respon spektral anakan tanaman, maka tingkat Ketahanan terhadap pencemaran udara dengan urutan sebagai berikut: nyamplung, tanjung, akasia, ketapang, dan mahoni.

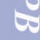

\subsection{Saran}

Beberapa saran penelitian yang perlu dilakukan: 1) penelitian respon radiasi špektral untuk jenis pohon perkotaan lainnya; 2) pengambilan sampel udara, untuk mengetahui secara pasti tingkat pencemaran udara pada lokasi penelitian; 3) penelitian pembanding berdasarkan tingkat pertumbuhan tanaman. 


\section{DAFTAR PUSTAKA}

Aldaghi M, Anderson R, Lopez M, Odom H, Pearse M. 2016. Controlled environment for plant production. Thesis Biosystem Engineering. 11 May 2016. University of Arizona

Carney MJ, Venetucci P, Gesick E. 2015. LED lighting in controlled environment agriculture. Minnesota Departement of Commerce.

Outsourched Innovation LLC. URL:http://www.Outsourcedinnovation.com

Chou MD. 1990. Parameterization for The Absorbtion of Solar Radiation by $\mathrm{O}_{2}$ and $\mathrm{CO}_{2}$ with Application to Climate Studies. Journal of Climate. 3: 209217.

Dahlan N. 1992. Hutan Kota : untuk pengelolaan dan peningkatan kualitas lingkungan hidup. Jakarta: Asosiasi Pengusaha Hutan Indonesia.

Dahlan EN. 2008. Jumlah emisi gas $\mathrm{CO}_{2}$ dan pemilihan jenis tanaman berdaya rosot sangat tinggi: studi kasus di Kota Bogor. J Media Konservasi. 13(2): 85-89

Grey GW, Deneke FJ. 1978. Urban Forestry. New York (US). John Wiley and Sons Inc.

Handoko P, Fajariyanti Y. 2013. Pengaruh spektrum cahaya tampak terhadap laju fotosintesis tanaman air Hydrilla verticillata. Seminar Nasional $\mathrm{X}$ Pendidikan Biologi FKIP UNS. Kediri : Universitas Negeri Sebelas Maret. 1-9.

Henning R. 1990. A Comparison of the contribution of various gases to the greenhouse effect. Journal of Science. 248(11): 1217-1219.

Hidayat I W. 2008. Evaluasi Jalur Hijau Jalan Sebagai Penyangga Lingkungan Sekitarnya dan Keselamatan Pengguna Jalan Bebas Hambatan Jagorawi [tesis]. Bogor : Institut Pertanian Bogor

Lantana DA. 2014. Pendugaan nilai radiasi spektral menggunakan transformasi fourier untuk menentukan usia dan kandungan pigmen citra daun jati belanda [tesis]. Bogor : Institut Pertanian Bogor

Nasrullah N, Soertini G, Herry S, Marietje W, dan Andi W. 2001. Seleksi Tanaman Lanskap yang Berpotensi Tinggi Menyerap Polutan Gas NO2 dengan Menggunakan Gas NO2 Bertanda 15N. Bulletin Taman dan Lanskap Indonesia Vol. 4/1/2001 : 1-5.

Nyamsi WW, Espinar B, BlancP, Wald L. 2015. Estimating the photosynthetically active radiation under clear skies by means of a new approach. Adv. Sci. Res. 12: $5-10$

Pitman JI. 2000. Absorption of photosynthetically active radiation, radiation use effeciency and spectral reflectance of bracken [Pteridium aquilinum (L) Kuhn] canopies. J of Annals of Botany. 85: 101-111

Prasetyo, E. 2012. Data Mining: Konsep Dan Aplikasi Menggunakan MATLAB. Penerbit ANDI. Yogyakarta.

Purbaya DA. 2016. Radiasi Spektral Beberapa Jenis Daun Pohon di Kampus IPB Darmaga [Skripsi]. Institut Pertanian Bogor.

Salisbury FR, Ross CW. 1992. Fisiologi Tumbuhan.Jilid ke-3. Terjemahan Diah RL. Bandung : ITB Press. 
Syafriyuddin. 2015. Pengaruh variabel warna lampu led terhadap pertumbuhan tanaman krisan. Dalam Priyambondo S, Saudah S, dan Ledhe NT. Prosiding seminar nasional teknik industri Sustainable Manufacturing. Yogyakarta, 3 Sep 2015. Institut Sains dan Teknologi AKPRIND.

Triono S. 2004. Potensi penyerapan karbondioksida pada akasia (Acasia crassicarpa) dan gmelina (Gmelina Arborea Linn.) berdasarkan model pertumbuhan logistik dan kurva respon cahaya [skripsi]. Bogor : Institut Pertanian Bogor.

Qin J, Yang K, Liang S, Tang W. 2011. Estimation of daily mean photosynthetically active radiaton under all-sky conditions based on relative sunshine data. Journal of Applied Meteorology and Climatology. 51: 150-160.

Zakrzewska AS, Kleiber T. 2014. The effect of light colour and type of lamps on rooting and nutrient status in cuttings of Michaelmas daisy. Bulg. J. Agric. Sci. 20: 1426-1434 


\section{LAMPIRAN}

Lampiran 1 Pengelompokkan nilai spektral pada gelombang biru

\section{Gelombang Biru (450-515 nm)}

\begin{tabular}{llll}
\hline Jenis & $\begin{array}{l}\text { Nilai Spektral } \\
(\mathrm{Wcm}-2 \mathrm{~nm}-1 \mathrm{sr}-1)\end{array}$ & Gerombol & Klasifikasi \\
\hline Mahoni (1) & 0,070848439 & 1 & Rendah \\
Tanjung (1) & 0,083184506 & 1 & Rendah \\
Nyamplung (1) & 0,09937249 & 2 & Sedang \\
Ketapang (1) & 0,101838605 & 2 & Sedang \\
Akasia (1) & 0,112901881 & 2 & Sedang \\
Tanjung (2) & 0,127597066 & 2 & Sedang \\
Nyamplung (2) & 0,148329316 & 2 & Sedang \\
Mahoni (2) & 0,176743286 & 3 & Tinggi \\
Ketapang (2) & 0,187605802 & 3 & Tinggi \\
Akasia (2) & 0,222193203 & 3 & Tinggi \\
\hline
\end{tabular}

Keterangan: (1) Kurang tercemar

(2) Tercemar

Lampiran 2 Pengelompokkan nilai spektral pada gelombang merah

\section{Gelombang Merah (630-680nm)}

\begin{tabular}{llll}
\hline Jenis & $\begin{array}{l}\text { Nilai Spektral } \\
(\mathrm{Wcm}-2 \mathrm{~nm}-1 \mathrm{sr}-1)\end{array}$ & Gerombol & Klasifikasi \\
\hline Tanjung (1) & 0,074307061 & 1 & Rendah \\
Mahoni (1) & 0,083815783 & 1 & Rendah \\
Nyamplung (1) & 0,099013277 & 1 & Rendah \\
Ketapang (1) & 0,100807039 & 1 & Rendah \\
Akasia (1) & 0,125977434 & 1 & Rendah \\
Tanjung (2) & 0,149271817 & 2 & Sedang \\
Nyamplung (2) & 0,175736063 & 2 & Sedang \\
Mahoni (2) & 0,201131583 & 3 & Tinggi \\
Ketapang (2) & 0,215316309 & 3 & Tinggi \\
Akasia (2) & 0,257996149 & 3 & Tinggi \\
\hline
\end{tabular}

Keterangan: (1) Kurang tercemar

(2) Tercemar 
Lampiran 3 Pengelompokkan nilai spektral pada gelombang hijau

Gelombang Hijau (525-600nm)

\begin{tabular}{llll}
\hline Jenis & $\begin{array}{l}\text { Nilai Spektral } \\
(\mathrm{Wcm}-2 \mathrm{~nm}-1 \mathrm{sr}-1)\end{array}$ & Gerombol & Klasifikasi \\
\hline Tanjung (1) & 0,128772197 & 1 & Rendah \\
Mahoni (1) & 0,130088525 & 1 & Rendah \\
Nyamplung (1) & 0,139915715 & 1 & Rendah \\
T.Ketapang (1) & 0,188619877 & 1 & Rendah \\
Akasia (1) & 0,199152454 & 1 & Rendah \\
Nyamplung (2) & 0,26524149 & 2 & Sedang \\
Tanjung (2) & 0,296812102 & 2 & Sedang \\
Mahoni (2) & 0,377123083 & 3 & Tinggi \\
Akasia (2) & 0,425946538 & 3 & Tinggi \\
Ketapang (2) & 0,444243646 & 3 & Tinggi \\
\hline
\end{tabular}

Keterangan: (1) Kurang tercemar

(2) Tercemar

Lampiran 4 Pengelompokkan nilai spektral pada gelombang NIR

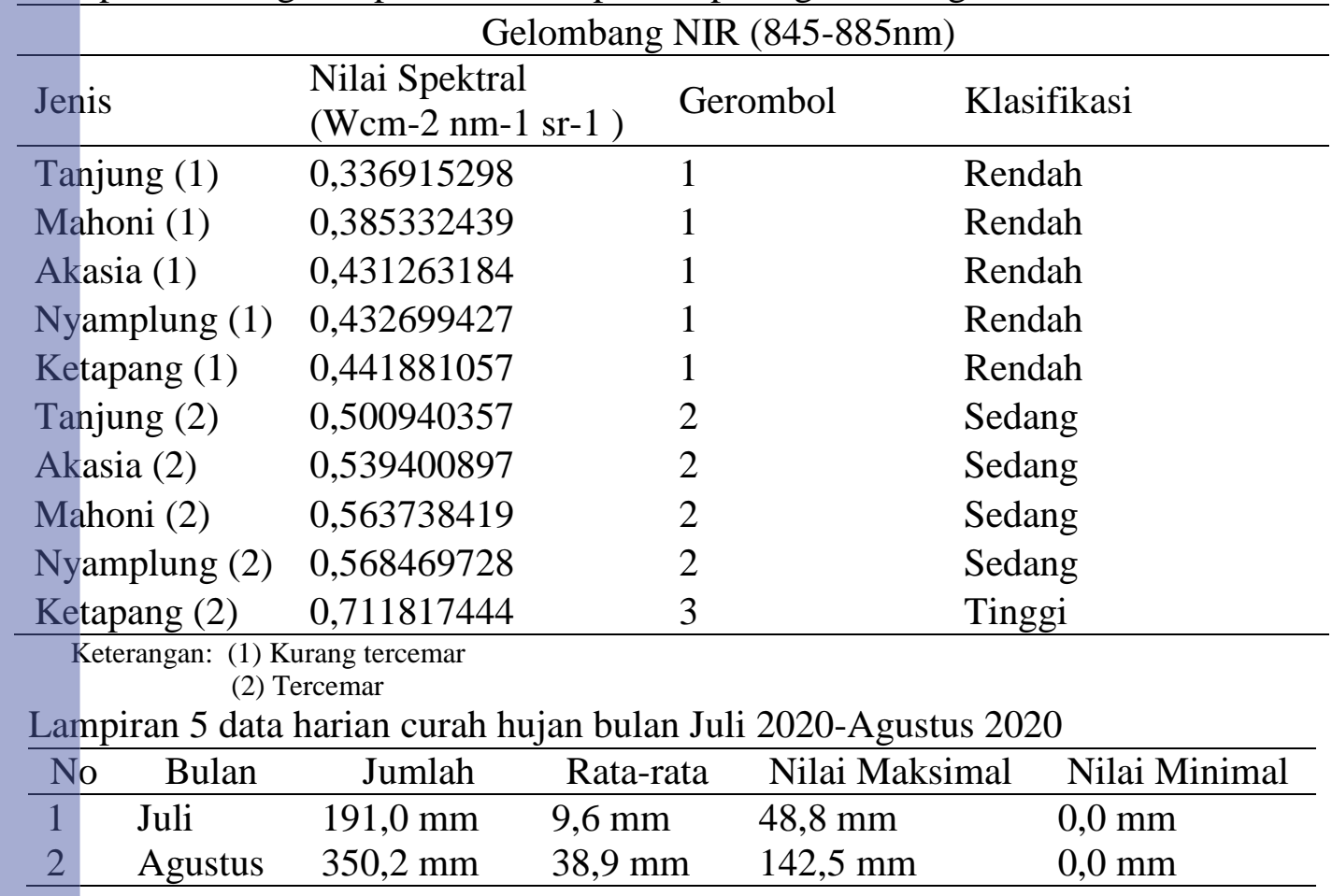


Lampiran 6 Hasil perhitungan clustering gelombang biru dengan SPSS

\section{Cluster Membership}

\begin{tabular}{|c|c|c|c|}
\hline Case Number & Jenis & Cluster & Distance \\
\hline 1 & Tanjung & 1 & .010 \\
\hline 2 & Nyamplung & 1 & .030 \\
\hline 3 & Mahoni & 2 & .019 \\
\hline 4 & Ketapang & 2 & .008 \\
\hline 5 & Akasia & 2 & .027 \\
\hline 6 & Mahoni & 3 & .006 \\
\hline 7 & Tanjung & 3 & .006 \\
\hline 8 & Nyamplung & 1 & .019 \\
\hline 9 & Ketapang & 1 & .016 \\
\hline 10 & Akasia & 1 & .005 \\
\hline
\end{tabular}

Lampiran 7 Hasil perhitungan clustering gelombang merah dengan SPSS

\section{Cluster Membership}

\begin{tabular}{|c|c|c|c|}
\hline Case Number & Jenis & Cluster & Distance \\
\hline 1 & Tanjung & 1 & .013 \\
\hline 2 & Nyamplung & 1 & .013 \\
\hline 3 & Mahoni & 2 & .024 \\
\hline 4 & Ketapang & 2 & .009 \\
\hline 5 & Akasia & 2 & .033 \\
\hline 6 & Tanjung & 3 & .022 \\
\hline 7 & Mahoni & 3 & .013 \\
\hline 8 & Nyamplung & 3 & .002 \\
\hline 9 & Ketapang & 3 & .004 \\
\hline 10 & Akasia & 3 & .029 \\
\hline
\end{tabular}


Lampiran 8 Hasil perhitungan clustering gelombang hijau dengan SPSS

\section{Cluster Membership}

\begin{tabular}{|c|c|c|c|c|}
\hline & Case Number & Jenis & Cluster & Distance \\
\hline \multirow{2}{*}{$\frac{2}{2}$} & 1 & Nyamplung & 1 & .016 \\
\hline & 2 & Tanjung & 1 & .016 \\
\hline s. & 3 & Mahoni & 2 & .039 \\
\hline 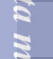 & 4 & Akasia & 2 & .010 \\
\hline तें & 5 & Ketapang & 2 & .028 \\
\hline 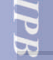 & 6 & Tanjung & 3 & .029 \\
\hline $\mathfrak{s}$ & 7 & Mahoni & 3 & .027 \\
\hline$\frac{5}{2}$ & 8 & Nyamplung & 3 & .017 \\
\hline : & 9 & Ketapang & 3 & .031 \\
\hline & 10 & Akasia & 3 & .042 \\
\hline
\end{tabular}

Lampiran 8 Hasil perhitungan clustering gelombang NIR dengan SPSS

\section{Cluster Membership}

\begin{tabular}{|c|c|c|c|}
\hline Case Number & Jenis & Cluster & Distance \\
\hline 1 & Tanjung & 2 & .042 \\
\hline 2 & Akasia & 2 & .004 \\
\hline 3 & Mahoni & 2 & .021 \\
\hline 4 & Nyamplung & 2 & .025 \\
\hline 5 & Ketapang & 3 & .000 \\
\hline 6 & Tanjung & 1 & .069 \\
\hline 7 & Mahoni & 1 & .020 \\
\hline 8 & Akasia & 1 & .026 \\
\hline 9 & Nyamplung & 1 & .027 \\
\hline 10 & Ketapang & 1 & .036 \\
\hline
\end{tabular}




\section{RIWAYAT HIDUP}

Penulis dilahirkan di Bogor pada tanggal 2 September 1998. Putri tunggal dari Bapak Adi Riyanto dan Ibu Maryani. Penulis lulus dari SDN Panaragan 1 Bogor pada tahun 2010, lalu melanjutkan pendidikan di SMPN 6 Bogor dan lulus tahun 2013. Kemudian, pada tahun 2016 penulis lulus dari SMA Plus Bina Bangsa Sejahtera dan Penulis diterima di Institut Pertanian Bogor (IPB) tahun 2016 melalui jalur Seleksi Bersama Masuk Perguruan Tinggi Negeri (SBMPTN) pada Departemen Konservasi Sumberdaya Hutan dan Ekowisata, Fakultas Kehutanan.

Selama mengikuti perkuliahan di IPB, penulis pernah mengikuti unit kegiatan mahasiswa MAX dan bergabung dengan organisasi kemahasiswaan Himpunan Mahasiswa Konservasi Sumberdaya Hutan dan Ekowisata (HIMAKOVA) sebagai anggota Fotografi Konservasi "FOKA" dan menjadi anggota Biro Kekeluargaan dan Kewirausahaan.

Penulis melaksanakan Praktik Umum Kehutanan (PUK) di Cilacap, Baturaden dan Hutan Pendidikan Gunung Walat - Fakultas Kehutanan IPB pada bulan Juli 2018. Penulis melaksanakan Kuliah Kerja Nyata-Tematik (KKN-T) di Desa Tambakromo, Kecamatan Malo, Kabupaten Bojonegoro tahun 2019. Selain itu, penulis juga pernah menjadi asisten mata kuliah Ilmu Hutan Kota pada tahun 2020, mengikuti Magang Online Fahutan di Direktorat Bina Usaha Perhutanan Sosial dan Hutan Adat (BUPSHA) Perhutanan Sosial dan Kemitraan Lingkungan (PSKL) Kementerian Lingkungan Hidup dan Kehutanan Jakarta pada tahun 2020, dan penulis juga mengikuti program IGTF IPB 2020. 